\title{
Soil Fertility on Dryland Areas of Bireuen District Aceh Province, Indonesia
}

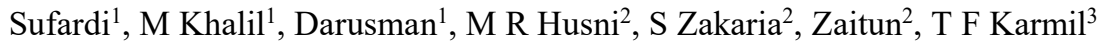 \\ Department of Soil Science, Faculty of Agriculture, Syiah Kuala University, Banda Aceh, Indonesia ${ }^{1}$ \\ Department of Agrotechnology, Faculty of Agriculture, Syiah Kuala University, Banda Aceh, Indonesia ${ }^{2}$ \\ Faculty of Veterinary Medicine, Syiah Kuala University, Banda Aceh, Indonesia ${ }^{3}$
}

\{sufardi_usk@unsyiah ac.id\}

\begin{abstract}
Soil fertility status is important information in soil management. Field studies and laboratory analyzes have been conducted to assess soil fertility status in some dryland areas in Bireuen District, Aceh Province (Indonesia). Soil samples taken from 26 sites in Bireuen Regency represented six types of soil namely Podzolic Haplic (Typic Hapludults), Regosol Humic (Typic Udipsamments), Alluvial District (Typic Udifluvents), Lithosol (Lithic Udorthents), Gleysol Eutric (Typic Fluvaquents) and Gleysol Humic (Typic Humaquepts). Soil samples were taken at the depths of $0-20 \mathrm{~cm}$, then taken to analyze some soil fertility properties including: $\mathrm{pH}$, organic $\mathrm{C}$, total $\mathrm{N}$, total $\mathrm{P} 2 \mathrm{O} 5$ and $\mathrm{K} 2 \mathrm{O}$ content $(25 \% \mathrm{HCl}$ extract), available $\mathrm{P}$ (Bray II), exchangeable cations $(\mathrm{Ca}$, $\mathrm{Mg}, \mathrm{K}$, and $\mathrm{Na}$ ) and $\mathrm{CEC}$ (1N ammonium acetate $\mathrm{pH} 7$ method), exchangeable $\mathrm{Al}$ and $\mathrm{H}(1 \mathrm{M} \mathrm{KCl}$ extract), and electrical conductivity (EC). The results showed that the soil chemical characteristics in Bireuen dryland varied between soil types, but all the soils ware low fertility. The limiting factors of soil fertility are low soil organic matter $(<1.5 \%)$, low base saturation $(<35 \%)$, and low P2O5 and $\mathrm{K} 2 \mathrm{O}$ content. Soil $\mathrm{pH}$ varies from acid to neutral (5.04-7.02), while the CEC values, available P, varied from low to high. The exchangeable $\mathrm{Al}$ and $\mathrm{EC}$ values are generally very low. The main key to improving soil fertility status of dryland areas of Bireuen District is to provide ameliorant material in the form of organic matter, biochar, compost, and fertilizers.
\end{abstract}

Keywords: Dryland Farming, Soil Fertility, Constraints, Soil Improvement

\section{Introduction}

Dryland is one of the natural resources for agricultural development, especially in increasing the production of food crops, horticulture and plantations in order to maintain national food needs. In Indonesia, 63.4 million ha of dryland areas have been used for agricultural lands [1]. In Aceh Province the potential of dryland for agriculture is still very wide, reaching 1,154,445 ha. In Bireuen District the area of dryland that has the potential for agriculture reaches 79,238 ha while the rest is non-irrigated rice fields 6,946 ha, dryland area is 46,761 ha, fields are 21,892 ha, and the land is 3,639 ha [2]. The main obstacle in utilizing dryland for agriculture is the low level of soil fertility caused by a number of chemical constraints that limit plant growth such as acidity and nutrient availability [3].

According to Abdurachman, Dariah, \& Mulyani [4], the area of dryland generally has low soil fertility which indicated by low soil organic matter, low base saturation, and low nutrient availability. This condition is exacerbated by the limited use of organic fertilizers, especially for the annual food crops. In addition, naturally, the levels of soil organic matter in the tropical regions are rapidly decreasing reaching 30-60\% within 10 years [5]. Carbon from organic bonds is generalized by microorganisms to carbon dioxide so that gradually soil organic matter decreases [6], [7]. Another problem of many soils on dryland in a humid tropical region dominated by acid soils especially in the orders of Ultisol, Oxisol, Inceptisol, Andisol, and Spodosol [3] which are often called as acid mineral soils [8]. These soils are characterized by low soil $\mathrm{pH}(\mathrm{pH}<6.5)$, low soil CEC, low cations content, and high phosphate fixation [3]. Sufardi, Muyassir, \& Martunis [9] have reported that most dryland of Aceh Besar District has low organic C and total N, low base saturation, and low cation nutrient availability, although there are variations between soil types. Other studies show that there are also some soils on dryland that have low soil CEC and low P available [10], [11] so that generally the quality is low. Research conducted by Husni, Sufardi, \& Khalil [12] states that in some dryland it turns out that it has a high soil CEC ( $>35 \mathrm{cmol} \mathrm{kg}-1)$ and also has a very high available $\mathrm{P}(>40 \mathrm{mg} \mathrm{kg}-1)$. From the results of the study indicate that the soil chemical 
characteristics in dryland vary depending on the level of development and type of soil, climate, and level of soil management.

Although information about the constraints and soil fertility in dryland farming systems has been known, but the specific information on each type of soil and agroclimatic zone is still limited, therefore, to obtain data on soil characteristics and soil fertility there is a need for field observations to obtain data on soil chemical characteristics on dryland, so that the management is more appropriate [13]. According to Lakitan \& Gofar [14] solutions that can be done to overcome the obstacles found in dryland in addition to finding alternative sources of water, the use of drought-resistant plants, effective and efficient management of irrigation systems, efforts to improve the quality and fertility of the soil are also important to be applied. This will succeed if the management is based on basic data from the results of the survey and laboratory analysis. This study aims to determine soil chemical characteristics and evaluate soil fertility status in some dryland areas in Bireuen District, Aceh Province.

\section{Materials and Method}

This research was carried out in Bireun District, Aceh Province (Indonesia). This study uses a descriptive survey method through field observation and laboratory analysis. Field observation was carried out to obtain primary data in the form of general biophysical conditions and soil type whereas the laboratory analysis was conducted to analyze soil chemical characteristics. The soil profile is made by digging the soil in threedimensional shape with a size of $100 \mathrm{~m} \times 150 \mathrm{~m} \times 150 \mathrm{~m}$ or by utilizing an open hill cliff.

Determination of soil type is done by observing and identify morphological of soil profile and diagnostic horizon characteristics. For this purpose soil samples were taken at each layer of the horizon and analyzed in the laboratory. To evaluate soil chemical characteristics and fertility status each soil type in dryland areas, at least 26 soil composite samples were collected from 26 sites of topsoil $(0-20 \mathrm{~cm})$ representing a range of soil types, and land use of dryland farming of Bireuen District, Aceh. These samples were analyzed for soil $\mathrm{pH}(\mathrm{KCl}$ and $\mathrm{H} 2 \mathrm{O}$ ), electrical conductivity (EC), organic carbon (Walkley \& Black method), total N (Kjeldahl method), available P (Bray II), cations and CEC (1N NH4-acetate buffered at $\mathrm{pH} 7)$, exchangeable $\mathrm{Al}$ and $\mathrm{H}(1 \mathrm{M} \mathrm{KCl}$ extract), $\mathrm{P} 2 \mathrm{O} 5$ and $\mathrm{K} 2 \mathrm{O}$ (extracted with $25 \% \mathrm{HCl}$ ), and electrical conductivity $(\mathrm{EC})$ measured by using EC-meter.

Identifications of soil type, soil morphology and soil properties of the sites based on two soil classification systems (the Bogor Soil Classification System 2014 and the USDA Soil Taxonomy system 2014). Interpretation of soil chemical properties is based on the assessment criteria for soil chemical properties and soil fertility status according to the Soil Research Centre (1983) [15] by using parameters of cation exchange capacity (CEC), base saturation $(\mathrm{KB})$, total $\mathrm{P} 2 \mathrm{O} 5$ and $\mathrm{K} 2 \mathrm{O}$, and organic $\mathrm{C}$ content.

\section{Results and Discussion}

The results of field survey at 26 sites indicated that dryland areas in Bireuen District can be grouped into six soil types i.e Podzolic Haplic (Typic Hapludults), Regosol Humic (Typic Udipsamments), Alluvial Dystric (Typic Udifluvents), Lithosol (Typic Udorthents), Gleysol Eutric (Mollic Fluvaquents), and Gleysol Humic (Typic Humaquepts) according to Indonesian Soil Classification (2014). This means that dryland areas of Bireuen District consist of three soil orders namely Ultisols, Entisols, and Inceptisols.

\subsection{Soil Chemical Properties}

\subsubsection{Soil pH and exchangeable Al}

Table 1 shows that the $\mathrm{pH} \mathrm{H} 2 \mathrm{O}$ of soils varies from $\mathrm{pH} 5.70$ to 7.02 (slightly acid to neutral). Soil type with neutral $\mathrm{pH}$ was found on Gleysol Eutric, while other soil types (Podzolic Haplic, Regosol Humic, Alluvial District, Lithosol, Gleysol Eutric, and Gleysol Humic) were categorized as soils with acid $\mathrm{pH}$. Based on these data it can be said that with the range of $\mathrm{pH}$ values above, in general, the soils on dryland areas in Bireuen District has a problem with soil acidity, so that in soil management it is necessary to add ameliorant which reduces soil acidity or by planting tolerant plants to soil acidity [16]. Although most soil types can be categorized as acid soils but based on the results of survey and analysis, no soil with acidic extreme $\mathrm{pH}$ or $\mathrm{pH}<4.50$. This is also supported by the soil analysis which indicated low exchangeable $\mathrm{Al}$ (Table 2). Furthermore, the $\mathrm{pH} \mathrm{KCl}$ of soils from each soil type was lower than the $\mathrm{pH}$ value of $\mathrm{H} 2 \mathrm{O}$ and the difference ranged from -0.85 to $-1.37 \mathrm{pH}$ units. This is an 
indication that the soils in dryland of Bireuen District have negatively charged because the negative values of $\Delta \mathrm{pH}$ are greater than -0.05 [8]. Comparison of $\mathrm{pH}$ values of $\mathrm{H} 2 \mathrm{O}$ and $\mathrm{pH}$ of $\mathrm{KCl}$ between soil types is more clearly can be seen in Figure 1 .

Table 1. Soil chemical properties of each soil type in dryland of Bireuen District

\begin{tabular}{|c|c|c|c|c|c|c|}
\hline Soil chemical characteristics & $\begin{array}{c}\text { Podzolic } \\
\text { Haplic }\end{array}$ & $\begin{array}{c}\text { Regosol } \\
\text { Humic }\end{array}$ & $\begin{array}{c}\text { Alluvial } \\
\text { District }\end{array}$ & Lithosol & $\begin{array}{l}\text { Gleysol } \\
\text { Eutric }\end{array}$ & $\begin{array}{c}\text { Gleysol } \\
\text { Humic }\end{array}$ \\
\hline $\mathrm{pH}\left(\mathrm{H}_{2} \mathrm{O}\right)$ & $5,70^{\mathrm{SA}}$ & $6,15^{\mathrm{SA}}$ & $6,44^{\mathrm{SA}}$ & $6,36^{\mathrm{SA}}$ & $7,02^{\mathrm{N}}$ & $6,18^{\mathrm{SA}}$ \\
\hline $\mathrm{pH}(\mathrm{KCl})$ & $4,46^{\mathrm{A}}$ & $5,04^{\mathrm{A}}$ & $5,59 \mathrm{SA}$ & $5,35^{\mathrm{A}}$ & $5,65 \mathrm{SA}$ & $5,21^{A}$ \\
\hline$\Delta \mathrm{pH}\left(\mathrm{pH} \mathrm{KCl}-\mathrm{pH} \mathrm{H} \mathrm{H}_{2} \mathrm{O}\right)$ & $-1,24 *$ & $-1,11^{*}$ & $-0.85^{*}$ & $-1,01 *$ & $-1,37 *$ & $-0,97 *$ \\
\hline Organic C (Walkley \& Black, \%) & $1,49^{\mathrm{b}}$ & $1,21^{\mathrm{b}}$ & $0,92^{\mathrm{a}}$ & $1,94^{b}$ & $1,88^{\mathrm{b}}$ & $1,14^{b}$ \\
\hline Total N (Kjeldahl, \%) & $0,26^{\mathrm{c}}$ & $0,15^{b}$ & $0,17^{b}$ & $0,19^{b}$ & $0,16^{\mathrm{b}}$ & $0,29^{c}$ \\
\hline Available P (Bray II, $\mathrm{mg} \mathrm{kg}^{-1}$ ) & $28,7^{\mathrm{e}}$ & $61,1^{\mathrm{e}}$ & $67,5^{\mathrm{e}}$ & $160,3^{\mathrm{e}}$ & $8,45^{\mathrm{c}}$ & $45,8^{\mathrm{e}}$ \\
\hline $\mathrm{P}_{2} \mathrm{O}_{5}(\mathrm{HCl} 25 \%, \mathrm{mg} / 100 \mathrm{~g})$ & $34,9^{\mathrm{c}}$ & $58,0^{\mathrm{d}}$ & $102,6^{\mathrm{e}}$ & $107,3^{\mathrm{e}}$ & $35,0^{\mathrm{c}}$ & $90,0^{\mathrm{e}}$ \\
\hline $\mathrm{K}_{2} \mathrm{O}(\mathrm{HCl} 25 \%, \mathrm{mg} / 100 \mathrm{~g})$ & $22,9^{\mathrm{c}}$ & $7,50^{\mathrm{a}}$ & $46,6^{\mathrm{d}}$ & $66,3^{\mathrm{e}}$ & $39,0^{\mathrm{c}}$ & $34,0^{b}$ \\
\hline \multicolumn{7}{|l|}{ Exchangeable cations: } \\
\hline Ca-exch $\left(\mathrm{cmol} \mathrm{kg}^{-1}\right)$ & $3,10^{\mathrm{b}}$ & $1,82^{\mathrm{a}}$ & $2,82^{b}$ & $3,03^{b}$ & $4,29^{b}$ & $2,30^{b}$ \\
\hline $\operatorname{Mg}$-exch $\left(\mathrm{cmol} \mathrm{kg}^{-1}\right)$ & $0,23^{\mathrm{a}}$ & $0,30^{\mathrm{a}}$ & $0,46^{\mathrm{b}}$ & $0,48^{b}$ & $0,89^{b}$ & $0,32^{a}$ \\
\hline $\mathrm{K}-\operatorname{exch}\left(\mathrm{cmol} \mathrm{kg}^{-1}\right)$ & $0,10^{\mathrm{a}}$ & $0,08^{a}$ & $0,11^{\mathrm{b}}$ & $0,11^{\mathrm{b}}$ & $0,10^{\mathrm{a}}$ & $0,10^{\text {a }}$ \\
\hline $\mathrm{Na}-\operatorname{exch}\left(\mathrm{cmol} \mathrm{kg}{ }^{-1}\right)$ & $0,17^{\mathrm{b}}$ & $0,18^{b}$ & $0,19^{b}$ & $0,20^{\mathrm{b}}$ & $0,19^{b}$ & $0,19^{b}$ \\
\hline $\mathrm{CEC}\left(\mathrm{cmol} \mathrm{kg}^{-1}\right)$ & $36,0 \mathrm{~d}$ & $16,0^{\mathrm{b}}$ & $21,6^{\mathrm{c}}$ & $28,4^{\mathrm{d}}$ & $43,4^{\mathrm{e}}$ & $19,2^{\mathrm{c}}$ \\
\hline Base saturation $(\%)$ & $11,6^{\mathrm{a}}$ & $14,3^{\text {a }}$ & $19,0^{\text {a }}$ & $13,4^{\text {a }}$ & $12,7^{\mathrm{a}}$ & $15,1^{\text {a }}$ \\
\hline $\mathrm{Al}-\operatorname{exch}\left(1 M \mathrm{KCl},\left(\mathrm{cmol} \mathrm{kg}^{-1}\right)\right.$ & $1,25^{\mathrm{b}}$ & $0,00^{\mathrm{a}}$ & $0,00^{\mathrm{a}}$ & $0,00^{\mathrm{a}}$ & $0,00^{\text {a }}$ & $0,00^{\text {a }}$ \\
\hline $\mathrm{H}-\operatorname{exch}\left(1 M \mathrm{KCl}, \mathrm{cmol} \mathrm{kg}^{-1}\right)$ & $3,25^{\mathrm{a}}$ & $3,20^{\mathrm{a}}$ & $2,50^{\mathrm{a}}$ & $2,40^{\mathrm{a}}$ & $2,10^{\mathrm{a}}$ & $2,34^{\text {a }}$ \\
\hline Electrical conductivity $\left(\mathrm{dS} \mathrm{m}^{-1}\right)$ & $0,16^{\mathrm{b}}$ & $0,07^{\mathrm{a}}$ & $0,08^{\mathrm{a}}$ & $0,12^{b}$ & $0,31^{\mathrm{b}}$ & $0,08^{a}$ \\
\hline
\end{tabular}

$\mathrm{SA} / \mathrm{A} / \mathrm{N}=$ slighty acid/acid/neutral; a/b/c/d/e = very low/low/medium/high/very high; *)very significant
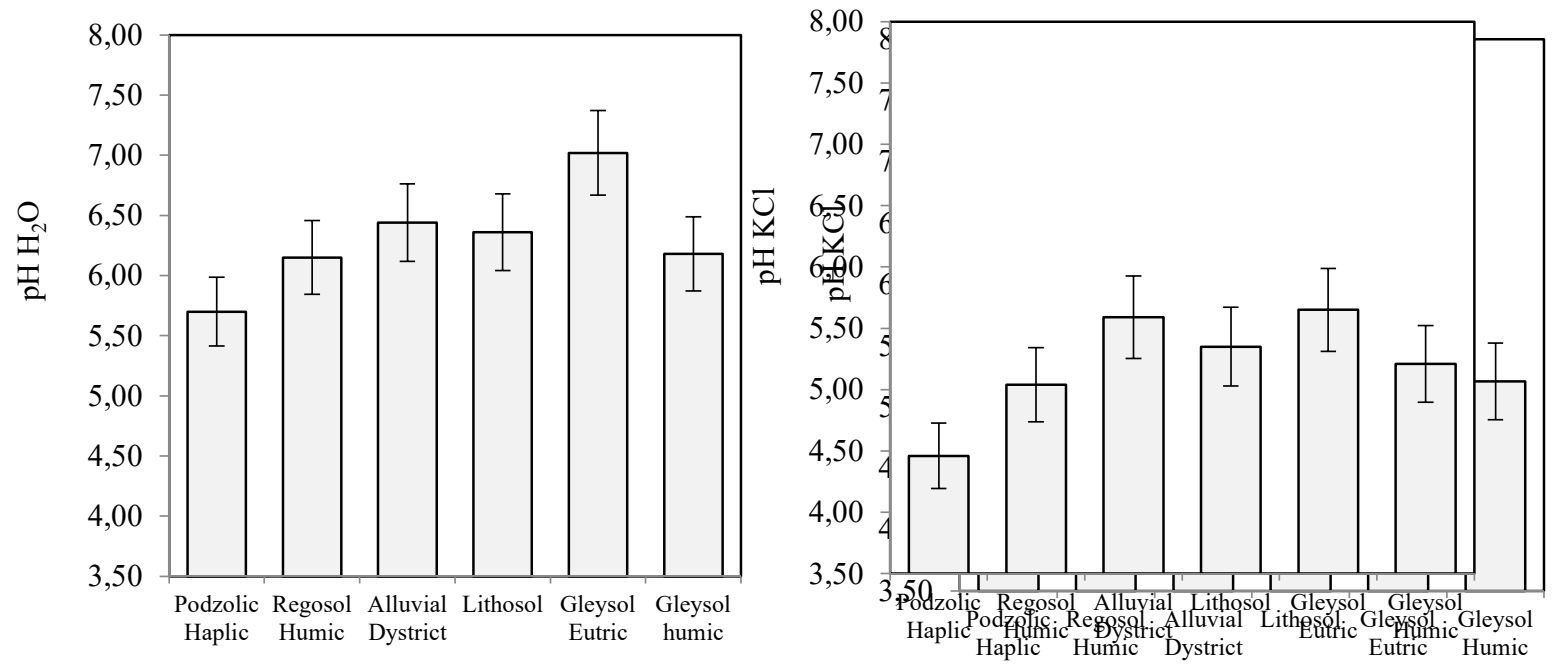

Figure 1. Soil $\mathrm{pH}$ value (pH-H2O and $\mathrm{pH}-\mathrm{KCl})$ in each soil type in dryland of Bireuen District

\subsubsection{Carbon and Nitrogen}

Organic matter is an important component of soil especially on soils in the tropical region. In these areas most soil have low of organic matter. Because of this, the keep of organic matters in the soils is very important to retain of soil quality. Table 1 shows that organic $\mathrm{C}$ content on dryland in Bireuen District is generally low and ranges from $0.92-1.88 \%$ (very low to low), while the total $\mathrm{N}$ of soil varies from 0.15 to $0.29 \%$ (low to medium). This data indicated that one of the problems in dryland in Bireuen District are low organic C and low N. From the Figure 2 it can be seen that the lowest organic $C$ was found at soil type of Alluvial District while the highest $\mathrm{C}$ was found on Lithosol and Gleysol Eutric. The low soil organic $\mathrm{C}$ because these soils are formed from sediment 
materials which are low of organic matter [12]. Soil organic matter content in these soil less 3\%. Sanchez [3] states that some of the characteristics of soils in tropical dryland are low organic matter. The results of the study are not much different from those reported by Sufardi et al [9] at Aceh Besar's dryland which also has a low total $\mathrm{C}$ and $\mathrm{N}$ contents.
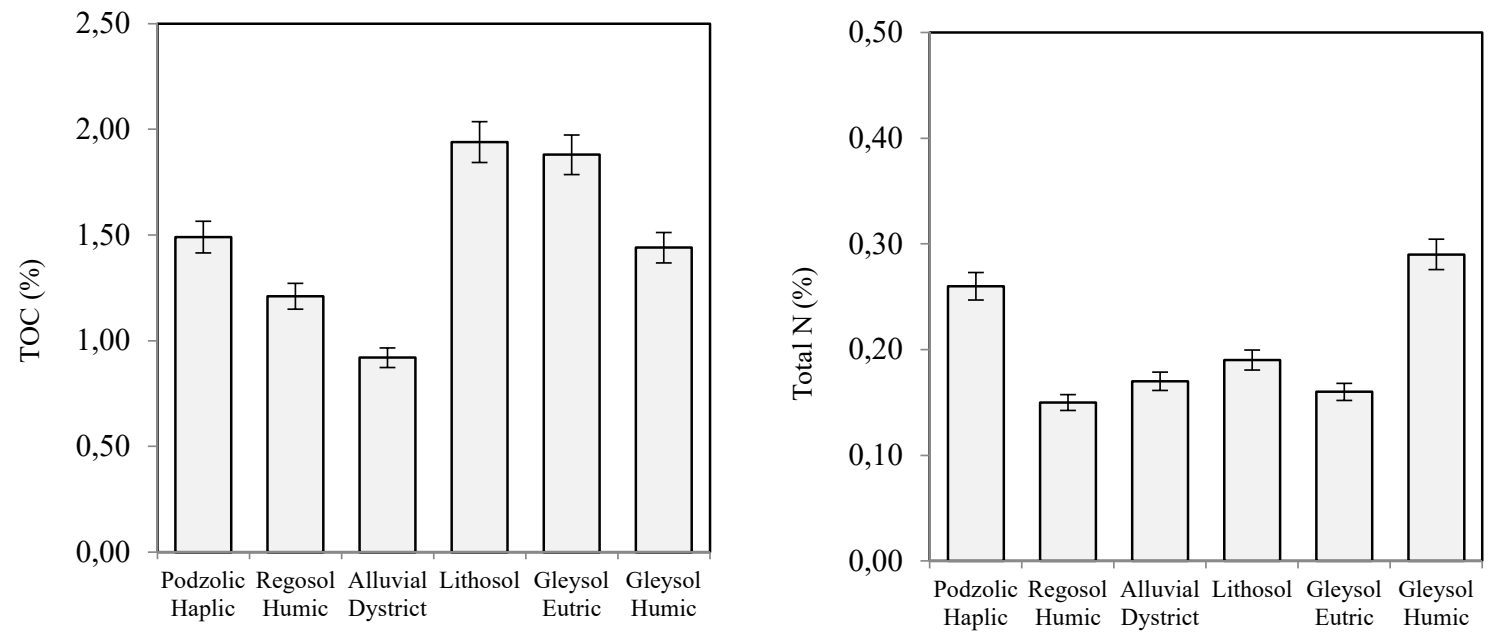

Figure 2. Total organic carbon (TOC) and total $\mathrm{N}$ in each soil type in dryland of Bireuen District

The content of soil organic matter reflects soil quality [6] because directly or indirectly can improve soil physical, chemical and biological properties [17], [18]. In the humid tropical region, most soils low of organic matter and usually only ranges from 1-5\% [17]. Therefore, efforts to maintain soil organic matter above 2 percent is highly recommended for tropical drylands [3]. Organic matter also functions as a source of nutrients especially $\mathrm{N}$, because in this material the $\mathrm{N}$ content can reach $3-5 \%$ [19].

\subsubsection{P2O5 and K2O}

Table 2 also shows that the total P2O5 content of soils in drylands of Bireuen District turned out to vary greatly in each soil type from moderate to very high, while available P varied from very low to very high. At Figure 2, the highest total P2O5 was found on Lithosol and Alluvial District soil types, while the lowest was found on Podzolic Haplic and Gleysol Eutric. The highest available P was also found on Lithosol and the lowest was on Gleysol Eutric. The high content of total P2O5 and available P on Lithosol because these soils are categorizedas undeveloped soil which formed from limestone (carst) parent material. This parent material is estimated to contain an apatite primary mineral which high phosphorus [19]. The difference in the total P2O5 and available $\mathrm{P}$ in each soil type of Bireuen District can be seen in Figure 3.

Furthermore, in Table 2 it can also be seen that the total $\mathrm{K} 2 \mathrm{O}$ content in each soil type of Bireuen District's dryland varies greatly ranging from very low to very high, while the exchangeable $\mathrm{K}$ value in almost all soil types is very low $(<0.2 \mathrm{cmol} \mathrm{kg-1})$. Based on this data it can be said that even though some of the soils in drylands of Bireuen District have sufficient potassium stock in the soils, but the availability of potassium is very low. The low exchangeable $\mathrm{K}$ may be due to source of potassium in soil found as original minerals form which difficult to decompose, so this K source does not correlate directly with the release of K into the soil solution. Havlin et a[19] state that the availability of potassium in the soil depends on the climate, type clay minerals, soil moisture, and soil CEC. Therefore, to increase the availability of potassium in soil solution, it is necessary to add fertilizer and organic matter. Organic matter can act as a solvent for soil minerals by reacting with organic acids [20], [21]. Figure 3 shows the difference in total $\mathrm{K} 2 \mathrm{O}$ content and exchangeable $\mathrm{K}$ between soil types. The content of exchangeable $\mathrm{K}$ in the soils is relatively same between soil types, except on Regosol Humic that lowest exchangeable $\mathrm{K}$ content, because this soil has a lot of sand fraction which is low in potassium. 

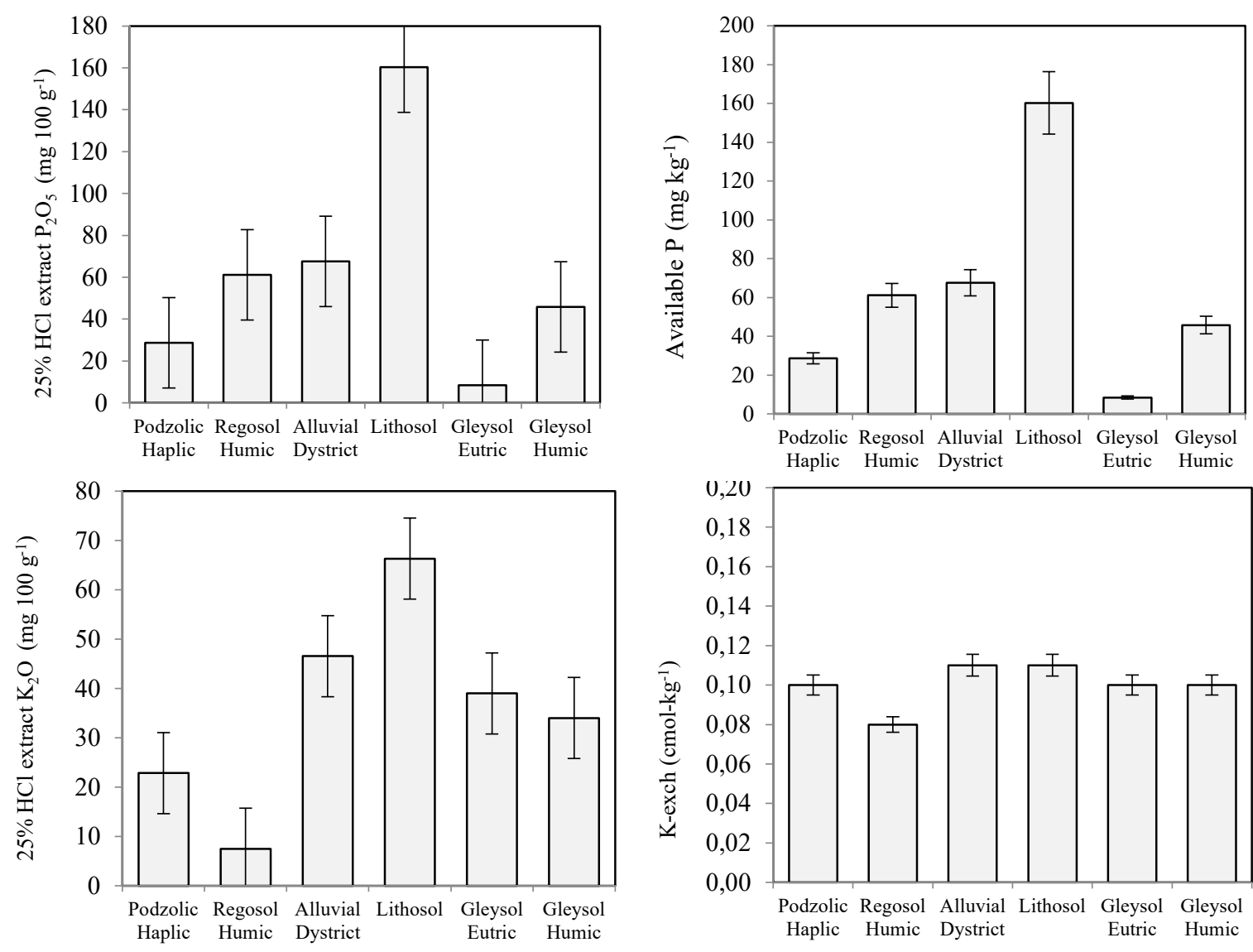

Figure 3. $\mathrm{P} 2 \mathrm{O} 5$ and $\mathrm{K} 2 \mathrm{O}(25 \% \mathrm{HCl}$ extract), available $\mathrm{P}$ and exchangeable $\mathrm{K}$ in each soil type in dryland of Bireuen District

\subsubsection{Exchangeable Ca, Mg, CEC and Base Saturation}

The results of laboratory analysis (Table 2) showed that the exchangeable Ca of soils in drylands of Bireuen District varied from very low to low (1.82 to $\left.4.29 \mathrm{cmol} \mathrm{kg}^{-1}\right)$, while exchangeable $\mathrm{Mg}$ also varied from very low to low ( 0.23 to $\left.0.89 \mathrm{cmol} \mathrm{kg}^{-1}\right)$. The highest values of exchangeable $\mathrm{Ca}$ and $\mathrm{Mg}$ were found on Gleysol Eutric soil type, while the other soil types of soil contained exchangeable Ca less $3 \mathrm{cmol} \mathrm{kg}^{-1}$ and exchangeable $\mathrm{Mg}$ of $<0.5 \mathrm{cmol} \mathrm{kg}^{-1}$ (Figure 4). Based on these data, it can be stated that the availability of $\mathrm{Ca}$ and $\mathrm{Mg}$ is a problem in drylands of Bireuen District because these two elements become the limiting factors for plant growth. Mengel \& Kirkby [20] suggest that $\mathrm{Ca}$ and $\mathrm{Mg}$ are macronutrients essential for plant growth. If one or both of these elements are in a limited (deficient) state in soil, the plant growth does not optimally [18], [19], [21]. Furthermore, Table 2 also shows that the value of CEC also varies between soil types from low to very high (16.0 to $43.4 \mathrm{cmol} \mathrm{kg}^{-}$ $\left.{ }^{1}\right)$. Figure 4 shows that the high CEC values $\left(>25 \mathrm{cmol} \mathrm{kg}^{-1}\right)$ were found on Gleysol Eutric followed by Podzolic Haplic and Lithosol, while low CEC $\left(<16 \mathrm{cmol} \mathrm{kg}^{-1}\right)$ were found on Regosol soil types.

Unlike the CEC value, percentage of base saturation (BS) in drylands of Bireuen District relatively similar between soil type and all of them are classified as low categories (11.6 to15.1\%). Based on these data, it can be stated that the low BS value of the soil is one of the obstacles found in Bireuen dryland because this BS value reflects the number of exchanged base cations that occupy soil colloids [7]. This statement is also evidenced from this study which shows that the cations such as $\mathrm{Ca}, \mathrm{Mg}, \mathrm{K}$, and $\mathrm{Na}$ in all soil types are included in the low category so that these values are correlated with base saturation values (Table 2). However, the low BS and base cations on this land are opposite to the $\mathrm{CEC}$ value. Usuall, the $\mathrm{CEC}$ value of the soil is proportional to the $\mathrm{KB}$ value and the number of base cations [22]. This is presumably because the soils have properties as variable charged soils as a common feature of soils in the tropics [8]. Van Ranst, Qafoku, Noble, \& Xu [23] suggested that one of the characteristics of variable charged soil is having amphibious colloidal properties. This property is characterized 
by mineralogical composition and soil organic matter [24]. Included in the soil with variable charge are Oxisol, Ultisol, Andisol, Spodosol, and Alfisol [25].
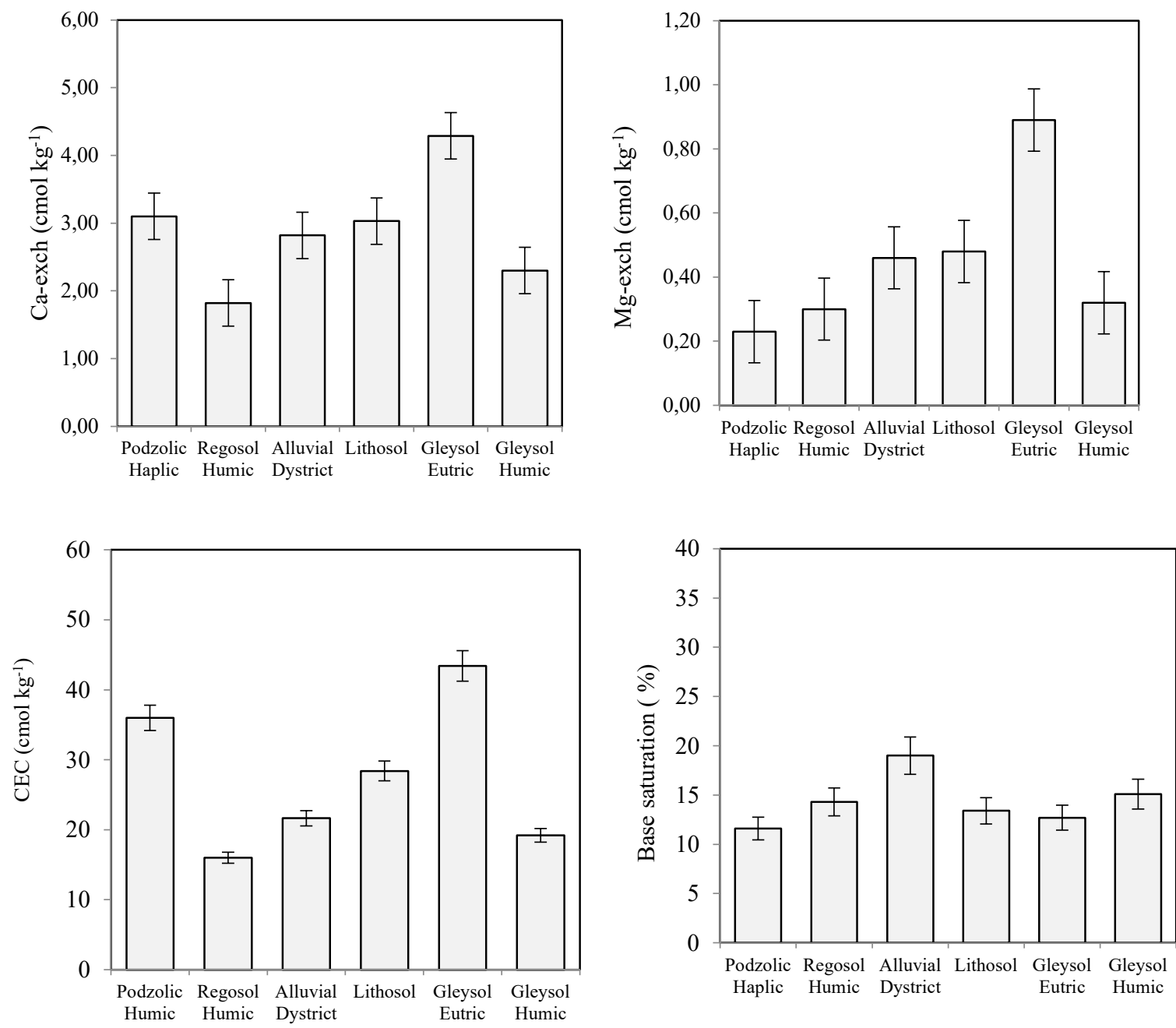

Figure 4. Exchangeable $\mathrm{Ca}$ and $\mathrm{Mg}, \mathrm{CEC}$ value, and base saturation of each soil types in dryland of Bireuen District

\subsubsection{Exchangeable Na and Electrical Conductivity (EC)}

Table 2 shows that the exchangeable Na of all soil types in dryland of Bireuen District has low criteria $(0.17$ to $\left.0.20 \mathrm{cmol} \mathrm{kg}^{-1}\right)$, while EC value is included in the criteria of very low to low $\left(0.07\right.$ to $\left.0.21 \mathrm{dS} \mathrm{m}^{-1}\right)$. Figure 5 shows that soil exchangeable $\mathrm{Na}$ is relatively not different between soil types and all have a value of $<0.2 \mathrm{cmol}$ $\mathrm{kg}^{-1}$. This shows that the soil on the dryland of Bireuen District is not indicated by salinity properties because all soil types low EC value. Based on this fact, there is no effect of salinity in the dryland of Bireuen District. 

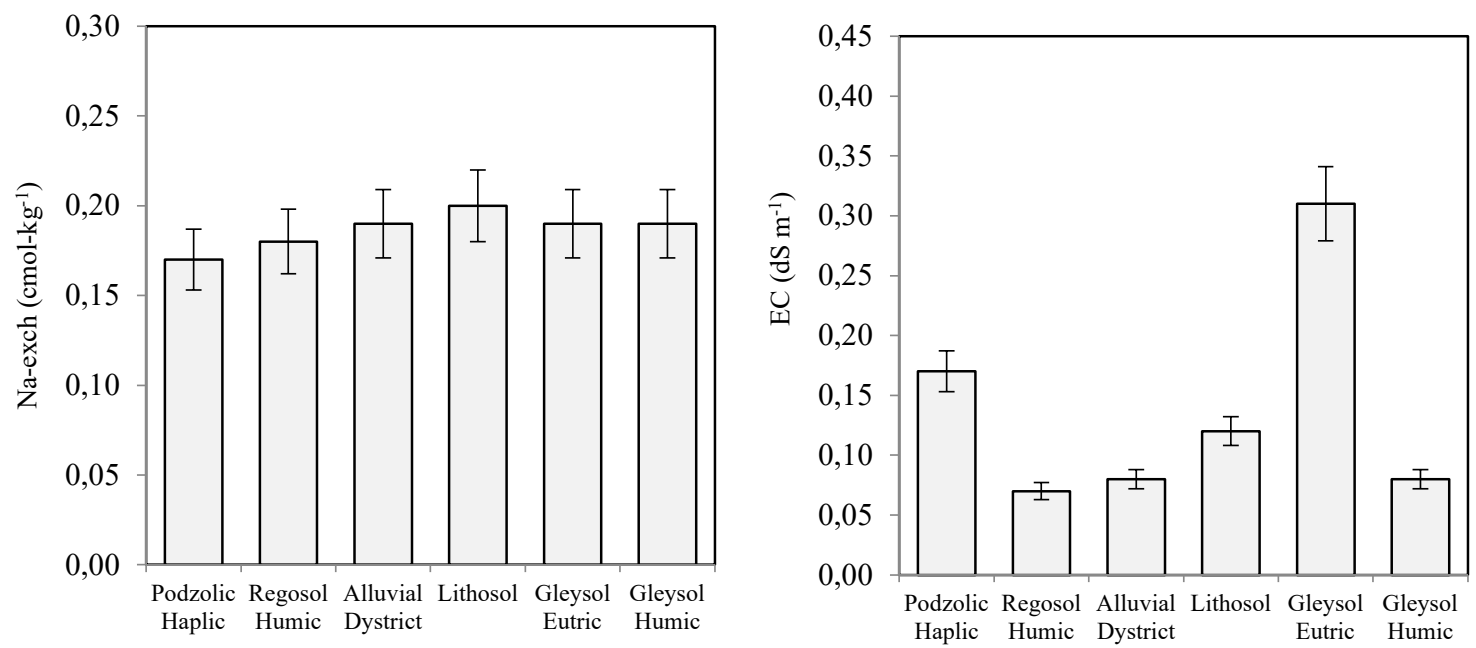

Figure 5. Exchangeable $\mathrm{Na}$ and electrical conductivity (EC) of each soil type in dryland of Bireuen District

\subsection{Soil Fertility Status}

The assessment of soil fertility status in each soil type in dryland of Bireuen District is presented in Table 2. The table shows that soil fertility status of all soil types is low criteria because there are several limiting factors. The limiting factors found in each soil type are different, but each soil type at least has 2 to 3 soil fertility parameters which are low or medium categories. Table 2 shows that the limiting factors found in dryland of Bireuen District are: (1) low organic C, (2) low base saturation, and (3) low total $\mathrm{K}_{2} \mathrm{O}$ content. Organic $\mathrm{C}$ in the soil is very important to maintain soil fertility and productivity. Bohn et al.[22] stated that organic matter greatly SW

Table 2. Evaluation of soil fertility status in dryland of Bireuen District

\begin{tabular}{clcccccc}
\hline No & $\begin{array}{l}\text { Soil Type } \\
\text { (SN 2014) }\end{array}$ & CEC & BS & $\mathrm{P}_{2} \mathrm{O}_{5}$ & $\mathrm{~K}_{2} \mathrm{O}$ & TOC & $\begin{array}{c}\text { Status of Soil } \\
\text { Fertility }\end{array}$ \\
\hline 1. & $\begin{array}{l}\text { Podsolik Haplic } \\
\text { (Typic Hapludults) }\end{array}$ & High & Low & Medium & Medium & Low & Low \\
2. & Regosol Humic & Low & Low & High & Low & Low & Low \\
3. & Alluvial Dystric & Medium & Low & High & High & Low & Low \\
4. & Lithosol & Medium & Low & High & High & Low & Low \\
5. & Gleysol Eutric & High & Low & Medium & Medium & Low & Low \\
6. & Gleysol Humic & Low & Low & High & Medium & Low & Low \\
\hline
\end{tabular}

$\overline{\mathrm{CEC}}=$ cation exchange capacity; $\mathrm{BS}=$ base saturation; $\mathrm{TOC}=$ total organic carbon 


\section{Conclusion}

Status of soil fertility in dryland farming of Bireuen District of each soil type is low because has 2-3 limiting factors. These factors can affect soil quality and crop production. The main problem of chemical aspects is soil acidity, low of exchangeable $\mathrm{Ca}, \mathrm{Mg}$, and $\mathrm{K}$, low total organic carbon (TOC) and low total $\mathrm{N}$. The content of $\mathrm{P}_{2} \mathrm{O}_{5}, \mathrm{~K}_{2} \mathrm{O}$, available $\mathrm{P}$, and CEC value of the soils are generally high, but the availability of $\mathrm{K}$ and base saturation are low. To improve soil fertility in dryland of Bireuen District it is necessary to add soil organic amendment in the form of organic matter, biochar, compost, and fertilizers. Further research is needed to examine the effects of soil amendment on soil productivity and crop production on dryland of Bireuen District.

\section{Acknowledgment}

This research is funded by the Australian Centre for International Agricultural Research, in ACIAR Project SMCN/2012/103 "Improving Soil and Water Management and Crop Productivity of Dryland Agriculture Systems of Aceh and New South Wales". Data collection was assisted by various undergraduate and postgraduate students at the University of Syiah Kuala, Banda Aceh, Indonesia.

\section{REFERENCES}

[1] _ Badan Pusat Statistik, Statistik pertanian Indonesia. Jakarta: Badan Penelitian dan Pengembangan Pertanian, 2016.

[2] BPS Bireuen, Bireuen dalam Angka. Bireuen: Badan Pusat Statistik Kabupaten Bireuen, 2013.

[3] P. A. Sanchez, Properties and management of soils in the tropics. New York: John Wiley \& Sons, 2010.

[4] A. Abdurachman, A. Dariah, and A. Mulyani, "Strategi dan teknologi pengelolaan lahan kering mendukung pengadaan pangan nasional," J. Litbang Pertan., vol. 27, no. 2, pp. 43-49, 2008.

[5] D. A. Suriadikarta, T. Prihatini, D. Setyorini, and W. Hartatiek, "Teknologi pengelolaan bahan organik tanah," in Teknologi Pengelolaan Lahan Kering Menuju Pertanian Produktif dan Ramah Lingkungan, Bogor: Pusat Penelitian dan Pengembangan Tanah dan Agroklimat, 2002, p. 183-238.

[6] F. J. Stevenson, Humus chemistry. Genesis-composition-reaction. New York: John Wiley \& Sons, 2010.

[7] G. Sposito, The chemistry of soils. London: Oxford University Press, 2008.

[8] G. Uehara and G. Gillman, The mineralogy, chemistry, and physics of tropical soils with variable charge clays. Boulder, Colorado: Westview Press, 1981.

[9] Sufardi, Muyassir, and L. Martunis, "Pertukaran kation pada beberapa jenis tanah di lahan kering kabupaten Aceh Besar provinsi Aceh (Indonesia)," in Seminar Nasional Pascasarjana Unsyiah, 2017.

[10] H. Helmi, H. Basri, and S. Sufardi, "Analysis of soil quality as hydrological disaster mitigation effort in Krueng Jreue sub-watershed, Great Aceh,” Aceh Int. J. Sci. Technol., vol. 6 , no. 2, pp. 75-85, 2017.

[11] L. Martunis, Sufardi, and M. Muyassir, "Analisis indeks kualitas tanah di lahan kering Kabupaten Aceh Besar Provinsi Aceh,” J. Budid. Pertan., vol. 12, no. 1, pp. 34-40, 
2017.

[12] M. R. Husni, Sufardi, and M. Khalil, "Evaluasi status keseburan pada beberapa jenis tanah pada lahan kering kabupaten Pidie provinsi Aceh," J. Ilm. Mhs. Fak. Pertan., vol. 1, no. 1, pp. 1-10, 2016.

[13] A. Mulyani and A. Hidayat, "Increasing the production capacity of upland food crops," J. Sumberd. Lahan, vol. 3, no. 2, pp. 1-22, 2012.

[14] B. Lakitan and N. Gofar, "Kebijakan inovasi teknologi untuk pengelolaan Lahan Suboptimal Berkelanjutan," in Seminar Nasional Intensifikasi Pengelolaaan Lahan Suboptimal Mendukung Kemandirian Pangan Nasional, 2013.

[15] _ Soil Research Centre, Term of reference of land capability survey. Bogor: Proyek Penelitian Pertanian Menunjang Transmigrasi (P3MT), 1983.

[16] P. A. Sanchez and P. Salinaz, "Effect of lime on exchangeable Al and corn growth," Soil Sci, vol. 23, pp. 89-92, 1982.

[17] A. Bot and J. Benites, "The importance of soil organic matter key to drought-resistant soil and sustained crop production," FAO soils Bull., p. 80, 2005.

[18] Sufardi, Pengantar nutrisi tanaman. Banda Aceh: Bina Nanggroe, 2012.

[19] J. L. Havlin, S. L. Tisdale, W. L. a Nelson, and J. D. Beaton, Soil fertility and fertilizers, 8th ed. New York: John Wiley and Sons, 2010.

[20] K. Mengel and E. A. Kirkby, Principles of plant nutrition. Worblaufen-Bern, Switzerland: International Potash Institute, 1987.

[21] H. Marschner, Marschner's mineral nutrition of higher plants. Amsterdam, Netherlands: Elsevier/Academic Press, 2012.

[22] H. L. Bohn, B. L. McNeal, and G. A. O'Connor, Soil chemistry. New York: John Wiley \& Sons, 2007.

[23] E. Van Ranst, N. P. Qafoku, A. Noble, and R. Xu, "Variable charge soils : mineralogy and chemistry," in Encyclopedia of soil science, 3rd ed., R. Lal, Ed. Boca Raton, FL: CRC Press Taylor \& Francis, 2017, pp. 2432-2439.

[24] G. P. Gillman, "Using variable charge characteristics to understand the exchangeable cation status of oxic soils," Aust. J. Soil Res., vol. 22, no. 1, pp. 71-80, 1984.

[25] B. K. G. Theng, Soil with variable charge. Lower Hutt, New Zealand: Department of Scientific and Industrial Research. Soil Bureau, 1980.

[26] Tolaka, "Sifat fisika tanah pada hutan primer lahan agroforestri dan kebun kakao," $J$. War. Rimba, vol. 1, no. 1, pp. 25-34, 2013. 